\title{
Servikal dejeneratif patolojilere bağlı kök basısı ve irritasyonuna sekonder boyun ve kol ağrısına nöroşirurjikal yaklaşım
}

\author{
Neurosurgical approach to neck and arm pain secondary to root compression and \\ irritation due to cervical degenerative pathologies
}

\author{
Erkin Özgiray \\ Ege Üniversitesi Tıp Fakültesi Hastanesi, Beyin ve Sinir Cerrahisi Anabilim Dalı, Bornova, İzmir
}

\begin{abstract}
Boyun ve kol ağrısı, bel ve bacak ağrısıyla birlikte insanların yaşam boyu karşılaştıkları rahatsızlıkların önde gelenlerinden bir tanesidir. Omurganın lomber ve dorsal kısmından kaynaklanan ağrılarda olduğu gibi, servikal omurgada da enfeksiyondan tümörlere ve travmalara dek birçok patolojik durum altta yatan neden olabilir. Bu derlemede tanısal ve cerrahi yaklaşımları çok farklılıklar gösterebilen diğer etiyolojiler kapsam dışında tutulmuş ve ağrının en sık nedeni olan dejeneratif değişikliklere bağlı kök basısı ve irritasyonu konu edilmiştir. Servikal omurganın dejeneratif değişikliklerine sekonder gelişen boyun ve kol ağrısının tek çözümü elbette cerrahi olmamakla birlikte, insanlığın muhtemelen yüzlerce yıldır uyguladığı masaj, ağrı kesiciler, fizik egzersiz gibi tutucu tedavilerin yanında güçlü bir seçenek olarak değerlendirilmelidir. Cerrahi kararı verilen olgularda seçilecek yöntemde olgunun özellikleri kadar cerrahi ekibin tecrübesi ve teknik donanımı da göz önüne alınmalıdır.
\end{abstract}

Anahtar sözcükler: boyun ve kol ağrısı; servikal omurga; dejeneratif patolojiler; cerrahi yaklaşım

\begin{abstract}
Neck and arm pain is one of the leading diseases with high prevalence. Etiology may differ from trauma to infections and tumors of the cervical spine. The pathologies other than degenerative diseases all deserve different approaches in terms of diagnosis, management and micro-neurosurgery and are not in the scope of this review. Although micro-neurosurgical decompression is not the first and only solution for most cases, it should be considered as the approach with acute and robust outcome for the selected patients who present no response to non-surgical therapies. Surgical approach should be tailored to every other case regarding the patient and the degenerative pathology as well as the surgical team, its experience and technical availabilities.
\end{abstract}

Key words: neck and arm pain; cervical spine; degenerative diseases; neurosurgical approach

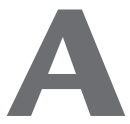

ğrının uluslararası kabul gören tıbbi tanımı, ağrı çalışma grubu tarafından yapılmıştır. Bu tanımlamaya göre ağrı, var olan ya da olası bir doku hasarıyla ilişkili olarak algılanan, hoş olmayan bir duyu ya da duygusal deneyimdir. ${ }^{[1]}$ Nosiseptif (ya da inflamatuvar) ve nöropatik olarak ikiye ayrılarak sınıflandırılabilir. Ağrı, tüm vücutta herhangi bir doku ya da organın hasarı sonucu ortaya çıkabilir. Tüm omurga göz önüne alındığında ağrının başlıca nedenleri olarak, omurgayı oluşturan yapıların enfeksiyonundan primer ya da sekonder malignite ve travmaya dek etkenler sayılabilir. Ancak, adjuvan tedaviler de gerektiren tümörler ile oluş mekanizmaları ve eşlik eden nörolojik defisitlere göre birbirinden çok farklı ileri spinal cerrahi teknikler ve enstrümantasyon gerektiren travmatik patolojiler, bu derlemenin kapsamı içerisine dahil edilmemiştir. Daha az sıklıkta karşılaşılan, servikal spondilodiskit ya da servikal epidural abseler gibi yangıya sekonder patolojilere cerrahi yaklaşımlar $\mathrm{da}$, benzer nedenlerle başka bir derleme konusu olarak ayrı tutulmuştur.

\section{EPIDEMIYOLOJi}

Birleşik Devletler ve Avrupa kaynaklı epidemiyolojik çalışmalara göre, erişkinlerde boyun ağrısı prevalansı neredeyse bel ağrısı kadar yüksektir. Ancak, çalışma sonuçları arasında oldukça büyük farklar

- İletişim adresi: Doç. Dr. Erkin Özgiray, Ege Üniversitesi Tıp Fakültesi Hastanesi, Beyin ve Sinir Cerrahisi Anabilim Dalı, Bornova, İzmir Tel: 0232 - 3905339 e-posta: eozgiray@gmail.com

- Geliș tarihi: 20 Șubat 2017 Kabul tarihi: 20 Șubat 2017 
bulunabilmektedir. Tüm omurga göz önüne alındığında, ömür boyu prevalansın \%4,7 kadar düşük bildirildiği yayınlar yanında, \%74,4'e dek yükseldiği çalışmalar da vardır. Öte yandan, farklı oranlar bildirilmesine rağmen, yaşla birlikte prevalansın da arttığı genel olarak kabul edilmektedir. ${ }^{[2]}$ On sekiz yaşından büyük erişkin nüfusun \%70'e yakın kısmı, hayatının bir devresinde boyun ağrısıyla karşılaşmaktadır. Cote ve arkadaşlarına göre, yaş standardizasyonu yapılmış erişkin nüfusta düşük yoğunluklu ve düşük disabiliteye neden olan boyun ağrısının altı aylık prevalansı $\% 39,7$ gibi yüksek bir orandır. ${ }^{[3]}$ Erişkin popülasyonda, bel ağrısı gibi boyun ağrısının da oldukça sık karşılaşılan bir yakınma olmasına karşın, adolesan ve çocuklarda boyun ağrısıyla karşılaşma sıklığını araştıran az sayıda çalışma vardır. Aartun ve arkadaşları, 11-13 yaş grubunda iki yıl devam eden ve tüm omurgayı kapsayan ileriye dönük bir çalışma yürütmüşlerdir. Danimarka'da beşinci ve altıncı sınıf öğrencileriyle yürütülen bu çalışmada, tüm omurga ağrısı prevalansının \%90'lara yaklaşması oldukça ilgi çekicidir. Çalışmaya göre, çocukların omurga ağrıları sıklıkla şiddetli olmamakla beraber daha yoğun ağrı yaşayan grubun ağrı ataklarının da daha sık olduğu bulunmuştur. Spesifik olarak boyun ağrısı prevalansının, bel ağrısı ve sırt ağrısına göre hem çalışmanın başlangıcı olan 11-13 yaş grubunda hem de bitiş noktası olan 13-15 yaş grubunda \%81,8'e kadar çıkarak, daha fazla olduğu saptanmıştır. Örneğin; $11-13$ yaş grubundaki 625 kız öğrencide omur boyu bel ağrısı prevalansı \%48,5, omur boyu sırt ağrısı prevalansı \%61,1 oysa boyun ağrısı prevalansı \%78,6 olarak saptanmıştır. Yazarlar, 11-15 yaş grubu çocuklarda tüm omurga ve boyun ağrısı prevalansının yüksek olduğu, ancak çoğunluğunun ağrı şiddetinin orta düzeyde kaldığı sonucuna varmışlardır. Yazarlara göre, adolesanların ancak \%14-20'i ağrıdan daha fazla ve sık etkilenmektedir. ${ }^{[4]}$

\section{ANAMNEZ VE MUAYENE}

Servikal omurganın dejeneratif değişikliklerinden kaynaklanan kök basısı hastalar, genellikle boyun ağrısı ve etkilenen kökün dermatomunda ağrı yanında, uyuşma, skapular ya da para-skapular ağrı, hissizlik, yanma gibi yakınmalarla karşımıza gelirler. Fizik bakıda, üst ekstremitede derin tendon reflekslerinde (biseps ve triseps) değişiklikler ve dirsek, el bileği fleksiyon ya da ekstansiyonunda güçsüzlükler saptanabilir. ${ }^{[5]}$

İleriye dönük bir çalışmada, tek bir seviye kök basısına $(C 5,6,7,8)$ neden olan ve servikal disk herniyasyonu (S HNP) tanısıyla ameliyat edilen 100 olguda, cerrahi bası bulgularıla operasyon öncesinde muayene bulgularının korelasyonu değerlendirilmiştir. ${ }^{6]}$ Olguların operasyon öncesinde tespit edilen muayene bulguları arasında; biseps, triseps, brakiyoradyalis reflekslerinin azalması, kas güçsüzlüğü ve uyuşma tespit edilmiştir. Başvuru yakınmaları ise boyun, kol, ön-kol, el, omuz, skapular ve inter-skapular bölgede ağrı, ön-kol ve elde parestezi, kolda güçsüzlük olarak tespit edilmiş; kolda tarif edilen ağrının, olguların ancak \%23'ünde ilgili kök basısıyla korele olduğu saptanmıştır. Ön-kolda tarif edilen ağrı ya da uyuşmanın ise, sırasıyla \%32'si tek kök, \%66'si çift kök basısı ile korele bulunmuştur. Hastanın tarif ettiği subjektif güç kaybı yakınmasının ise olguların \%79'unda tek seviye bası ile korele olduğu görülmüştür. Derin tendon reflekslerinin (DTR) azalması ya da kaybının saptandığı olgularda korelasyon oranları daha yüksek bulunmuş, \%11'nin tek kök, \%82'sinin ise iki kök basısı ile uyumlu olduğu görülmüştür. Yazarlar, bu 100 olguluk ileriye dönük çalışma sonucunda, el ve parmaklardan elde edilen klinik bulguların ilgili kök basısıyla daha uyumlu olduğunu saptamışlar; tek seviyeli S HNP'lerin neden olduğu dermatomal yakınma ve bulguların, diğer komşu köklerle çakışabildiğini bildirmişlerdir.

2006'da yayımlanan daha yeni bir ileriye dönük çaıışmada ise, servikal kök basısına sekonder radikülopati bulguları olan 50 ardışık olguda, kök basısıyla boyun ve skapula bölgesinde tarif edilen ağrının ilişkisinin ortaya konması amaçlanmıştır. ${ }^{[7]}$ Tanaka ve arkadaşları, çalışmanın bir diğer amacını ise, tarif edilen ağı bölgesinin bası altındaki kök seviyesini tespit etmedeki yararlılı̆ının değerlendirilmesi olarak bildirmişlerdir. Olgulara, cerrahi yöntem olarak, posterior yaklaşımla açık foraminotomiyle tek seviye kök dekompresyonu uygulanmış; buna, dekompresyon uygulanacak kök semptomlarının ve radyolojik görüntülemelerin birlikte değerlendirilmesiyle karar verilmiştir. Olgulardan yirmi tanesi S HNP tanısı alırken otuzu ise foraminal stenoz tanısı almış. Tanaka ve arkadaşlarına göre, boyun ve skapular ağrı, olguların \%70'inde el ve kol ağrısından daha ön plandaydı. Yazarların bulgularına göre, ağrının supra-skapular olduğu durumlarda kök etkilenmesi daha sıklıkla C5 ve C6'daydı. İnter-skapular yerleşimli ağrılarda ise kök etkilenmesi daha sıklıkla $C 7$ ve C8'deydi. Skapula üzerinde tarif edilen ağrılarda, etkilenen kök daha sıklıkla C8 olarak bulunmuştu. Erken cerrahi sonrası dönemde, tüm hastalar el ve kol yakınmalarında iyileşme bildirmişlerdir. Çalışmada, dekompresyon uygulandıktan bir ay sonra yakınmalarda tam düzelme bildiren hasta sayısı 27 idi. Bir yıllık izlem sonunda ise, hiç ağrısı olmayan hasta sayısı 45 iken, beş hastanın toplam altı farklı bölgede ağrı yakınması vardı. Üç olgunun ağrısı cerrahi öncesiyle aynıydı. 
Yazarlar, bu ileriye dönük cerrahi serisi sonucunda, skapular, inter-skapular ve supra-skapular bölge ağrılarının servikal kök basılarından kaynaklanabileceği ve ağrı bölgesinin etkilenen servikal kök seviyesine işaret edebileceği hükmüne varmışlardır. ${ }^{[7]}$

C 6-7 diskektomi uygulanarak ameliyat edilen 241 ardışık olgunun geriye dönük olarak değerlendirildiği klinik seride, Özgür ve arkadaşları, olguların \%83'ünde tipik C7 kok bulgularının var olduğunu bildirmektedirler. ${ }^{\left[{ }^{[8]}\right.}$ Ancak, arta kalan \%17'de izole sub-skapular ağrı ya da derin yerleşimli göğüs ağrısı atipik yakınmalarının mevcut olduğu ve bu atipik yakınmalardan \%93'ünün cerrahi dekompresyonla yarar gördüğünü belirtmektedirler.

Kuzey Amerika Omurga Derneği (North American Spine Society -NASS), 2010 yılında hazırladığı dejeneratif rahatsızlıklardan kaynaklanan radikülopatinin teşhis ve tedavisi kanıta dayalı kılavuzunda, elin intrensek kasları, deltoid kası zarifliği ya da göğüs ve baş ağrısı gibi atipik yakınmaların ve muayene bulgularının varlığında da, servikal kök etkilenmesinin göz önünde bulundurulması önerilmektedir. Bu kılavuza göre, atipik yakınmalar kök etkilenmeleriyle sıklıkla birlikte olabilmekte ve tedaviyle bu atipik yakınma ve bulgularda da düzelme görülebilmektedir. ${ }^{[5,9]}$

\section{BOYUN AĞRISIYLA BAŞVURAN OLGUDA RADYOLOJIK VE NÖROFIZYOLOJiK INCELEMELER}

\section{Manyetik Rezonans (MR) Görüntüleme}

Günümüzde radyolojik görüntüleme yöntemleri içerisinde, santral sinir sistemin ve servikal omurilik ve köklerin görüntülenmesinde en etkili yöntem MR'dir. Servikal radikülopati ve boyun ağrısının kanıta dayalı tanı ve tedavisi kılavuzunda MR, tutucu tedaviye yanıt alınamayan ve girişimsel (foraminal steroid enjeksiyonu vb.) ya da cerrahi yaklaşımlara aday olgularda kuşkulanılan patolojinin görüntüleme yöntemi olarak önerilmektedir.

Servikal radikülopatisi olan olgularda MR'nin tanısal doğruluğunun değerlendirilmesini amaçlayan ileriye dönük bir çalışma, van de Kelft ve arkadaşları tarafından yürütülmüşşür. ${ }^{[10]}$ Çalışmaya başlangıçta, servikal radikülopatisi olan ve tutucu tedaviye yanıt vermeyen ve cerrahi girişim planlanan 100 olgu dahil edilmiştir. Ancak, bunlardan travma ya da geçirilmiş cerrahi öyküsü olan 18'i BT miyelografiye yönlendirilmiştir. Düz grafide kemik şpurları ya da spondilozis bulguları olan 23 olgu da ayrıca BT miyelografiye yönlendirilmiş, dolayısıyla 41 olgu çalışma dışında tutulmuştur. Çalışmaya dahil edilen ve MR incelemesi yapılan 59 olgudan 55'inde klinikle uyumlu lokalizasyon S HNP saptanmış; bunlardan 50'si ameliyat edilmiştir. Bu olgulardan sadece ikisinde, MR'de tespit edilemeyen kemik şpurlar cerrahi esnasında tespit edilmiş; MR bulguları cerrahi bulgularıyla \%94 oranında korelasyon göstermiştir. Yazarlar, servikal radikülopati bulgusu olan hastalarda düz grafilerle kombine edilen MR görüntülemenin non-invaziv ve uygun bir teknik olduğu sonucuna varmışlardır. ${ }^{[10]}$

Bir başka geriye dönük çalışmada, Wilson ve arkadaşları, servikal radikülopatisi olan hastalarda MR'nin kompresif lezyonları görüntülemedeki etkinliğini değerlendirmişlerdir. ${ }^{[11]}$ Cerrahi dekompresyon yapılan toplam 40 olgudan 32'sinin tanısı S HNP olarak cerrahi esnasında teyit edilmiştir. MR, tüm hastaların \%92'sinde cerrahi patolojiyi doğru olarak tanımlamıştır. Cerrahi sonrasında, olgulardan 31'i tamamen iyileştiği, sekizinde iyileşme tam olmadığı, bir olgunun ise takibinin yapılamadığı bildirilmiştir. Yazarlar, çalışma sonucunda, servikal radikülopatisi olan hastaların çoğunda cerrahi öncesi yapılması gerekli olan tek incelemenin MR görüntüleme olduğu sonucuna varmışlardır. BT miyelografinin ise ancak MR bulgularının olmadığı ama nörolojik defisiti olan EMG'si pozitif olgularda yararlı olabileceği ifade edilmiştir.

\section{BT Miyelografi}

NASS çalışma grubu tarafından, klinik yakınma ve muayene bulgularının MR ile uyumlu olmadığı durumlarda BT miyelografinin tanı konmasında yardımcı olabileceği bildirilmekte ve bu incelemenin yapılması önerilmektedir. ${ }^{[5]}$ BT miyelografi aynı zamanda, uygun olmayan mitral kapak replasmanlı olgular gibi, MR'nin yapılamadığı durumlarda da görüntüleme yöntemi olarak önerilmektedir.

MR, BT miyelografi ve sadece miyelografinin tanı etkinliğini değerlendirmek üzere Modic ve arkadaşları ileriye dönük bir çalışma yürütmüşlerdir. ${ }^{[12]}$ Çalışmaya toplam 63 hasta dahil edilmiş, bunlardan 52 'sine MR, BT miyelografi ve miyelografi uygulanmış ve 28 'i de ameliyat edilmiş; cerrahi dekompresyon sırasında karşılaşılan patolojiyle, görüntüleme yöntemleri değerlendirilmiştir. Buna göre, tanısal doğruluk oranı MR için \%74, BT miyelografi için \%85 ve miyelografi için \%67 olarak hesaplanmıştır. Cerrahi sırasında karşılaşılan patolojiyle cerrahi öncesi tanı uyumu MR ve BT miyelografi birlikte kullanılan olgularda \%90'a çıkmaktadır. Modic ve arkadaşları, MR görüntülemeyi duyarlı ancak daha az özgül olarak değerlendirmişlerdir. Bunda da, BT miyelografinin kemik dokuyu disk materyalinden daha iyi ayırt edebilmesi etkindir. 


\section{Nörofizyolojik Değerlendirmeler, EMG}

Servikal dejeneratif değişikliklere sekonder kök etkilenmesinde nörofizyolojik çalışmaların yüksek çözünürlüklü MR görüntülerine ek bir bilgi sağlayıp sağlamadığının değerlendirilmesi amacıyla, Ashkan ve arkadaşları geriye dönük bir çalışma yapmışlardır. ${ }^{[13]}$ Çalışmaya, tümüne cerrahi dekompresyon uygulanan 45 olgu dahil edilmiştir. Cerrahi sonrasında erken değerlendirmede, 36 olgu tam iyileşme bildirirken yedi olgunun radikülopatiye bağlı semptomlarında belirgin düzelme bildirmişlerdir. Cerrahi sonrasında tam ya da belirgin iyileşme bildiren olgulardan ancak 16 'sında (\%37) cerrahi öncesi incelemelerde hem MR hem de EMG pozitif olarak bulunmuş. Oysa, 24'ünde (\%56) MR pozitif iken EMG negatifmiş. MR bulguları olmayan üç olgudan sadece birinde, cerrahi girişim kararı pozitif EMG çalışmasına, diğer ikisinde ise cerrahi kararı pozitif olan $\mathrm{BT}$ miyelografi görüntüsüne dayandırılarak verilmiştir. ${ }^{[13]}$

MR ve klinik muayene sonucunda radikülopatisi tespit edilemeyen olgularda nörofizyolojik testlerin yararlılığı konusunda yeterli kanıt bulunamamakla birlikte, bu testlerin yapılmaması konusunda da aynı şekilde yeterli kanıt bulunamamıştır. ${ }^{[5]}$

\section{CERRAHI YAKLAŞIMLAR, SEÇENEKLER}

Prevalansı yasa ve toplumlara göre büyük değişiklikler göstermekle beraber, ömür boyu prevalansı $\% 80$ 'lere kadar yükselen boyun ve kol ağrısının, muhtemelen çağlar boyunca, birinci basamak tedavisinin çeşitli ağrı-kesici ajanlar ile masaj ve manevralardan oluşan tutucu tedavi olduğu açıktır. Ancak, NASS çalışma grubunun 2010 yılında yaptığı literatür taramasına karşın, dejeneratif değişikliklerden kaynaklanan radikülopati kaynaklı ağrının farmakolojik tedavisinde kanıta dayalı sonuçları olan bir çalışmaya rastlanılmamış olması ilginçtir. Çalışma grubu, gelecek için, sadece farmakolojik ajanların kullanıldığı ve etik kurulların izin vermesi halinde hiçbir tedavi almayan bir kontrol grubunun da dahil edildiği ileriye dönük çalışmaların planlanmasını tavsiye etmektedir. Benzer şekilde, ülkemizde resmiyet kazanmamış olmakla birlikte, Batı ülkelerinde şiro-praktis (chiropractice) adıyla uygulanan servikal manipülasyonların da etkinliğini değerlendiren kanıta dayalı bir çalışmaya rastlanmamıştır. Ancak, özellikle cerrahi girişim gerektiren komplikasyonların bildirildiği olgu sunumları ya da küçük olgu serileri vardır. ${ }^{[14-16]}$ NASS çalışma grubu, şiro-praktis sonuçlarını kanıta dayalı olarak değerlendiren çalışmaların yokluğunu göz önüne alarak, hastaları bu tip tedavilerin olası komplikasyonları konusunda uyarırken çok özenli davranılması gerektiğini belirtmektedir. Çünkü, literatürde bu tedaviden kaynaklanan komplikasyonlar sporadik olarak bildirilmekteyken, olası yararlı sonuçlarının gözden kaçıyor olması ihtimali de vardır

Cerrahi seçeneklerden bahsetmeden önce, servikal omurganın dejeneratif hastalıklarından kaynaklanan radikülopati sonucu gelişen ağrı ve diğer semptomların iyileştirilmesinde, cerrahi yöntemlerin diğer tıbbi ve girişimsel yöntemlere göre daha hızlı etki gösterdiğini söyleyebiliriz. ${ }^{[5]}$

Servikal kök basısı ya da irritasyonuna neden olan dejeneratif patolojilerin önde gelenlerinden biri, servikal disk herniyasyonlarıdır (S HNP). S HNP'ler, füzyonlu ya da füzyonsuz olarak, ilk kez Smith ve Robinson'un 1958'de yaptıkları tanımlamalardan bu yana, anterior servikal diskektomiyle tedavi edilmektedir. Lateral yerleşimli ve yumuşak (akut) S HNP'ler, anterior yaklaşımlardan başka posterior yaklaşımlarla da tedavi edilebilir. Posterior laminotomi-foraminotomi olarak da isimlendirilen bu yaklaşımda, servikal instabiliteye yol açmadan, fizyolojik hareketin de korunması sağlanabilir. ${ }^{17-19]}$

Sampath ve arkadaşları ${ }^{[20]}$, servikal radikülopatisi olan hastaların tedavi sonuçlarının değerlendiren çok merkezli ileriye dönük bir çalışmanın sonuçlarını yayımlamışlardır. Cerrahi tedavi seçenekleri olarak; anterior servikal diskektomi (AD), füzyonlu anterior servikal diskektomi (FAD) ve foraminotomi (F) uygulanmıştır. Cerrahi olmayan tedavi seçenekleri ise standardize edilmemiştir ve basit yatak istirahatinden boyunluk takılmasına, epidural steroid uygulanmasından non-steroid anti-inflamatuvarlara (NSAii) kadar geniş bir spektrumu kapsamaktadır. Olgu sayısı toplam 246 olarak bildirilmiştir. Bunlardan 160'। non-randomize olarak cerrahi olmayan tedaviler grubuna dahil edilmiş, 86 'sı ise yukarıda belirtilen uç cerrahi yöntemden birisiyle ameliyat edilerek kök dekompresyonu sağlanmıştır. Bu hastalardan ancak $155^{\prime}$ 'i son kontrole dek takipte kalmıştır. Bunlardan 104 'ü cerrahi olmayan, 51 'i ise cerrahi yöntemlerle tedavi edilmişlerdir. Nihai değerlendirmede, cerrahi uygulanan hastalarda başlangıç ağrı skorlarının daha yüksek olduğu görülmüştür. Tüm tedavi gruplarında, tedavi sonunda ağrı skorlarında anlamlı azalma sağlanırken, cerrahi uygulanan grupta sağlanan düşüş daha belirgin olmuştur. Cerrahi grupta, günlük yaşam aktivitelerinde anlamlı oranda iyileşme kaydedilmiştir. Ancak, yine cerrahi grupta, olguların \%26'nda belirgin ağrının devam ettiği görülmüştür. Sampath ve arkadaşları, çalışmanın sonunda, cerrahi ve cerrahi olmayan yöntemlerin hepsinin etkin olduğunu tespit etmekle birlikte, cerrahi tedavinin etkinliğinin daha fazla olduğu sonucuna varmışlardır. ${ }^{[20]}$ 


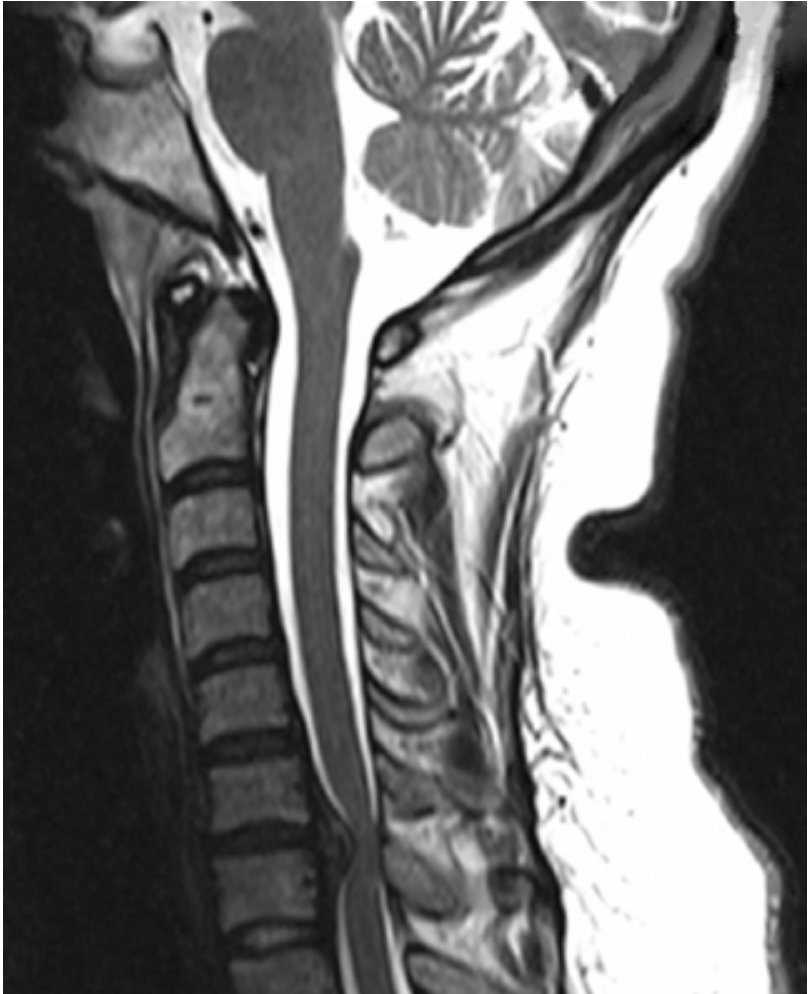

Şekil 1. Klinik serimizden, 38 yaşındaki kadın olguya ait MR görüntüde T2 sagittal kesitte görülen C 6-7 disk herniyasyonu (C 6-7 HNP). Cerrahi yönden değerlendirmeye alınan, servikal omurganın dejeneratif değişikliklerine bağlı kök basısı ön-tanılı tüm olgulara pre-kontrast MR uygulanmalıdır.

S HNP'ye sekonder kök basısını ortadan kaldırmak amacıyla ilk kez Smith ve Robinson tarafindan tarif edilen anterior yaklaşımla yapılan diskektomi cerrahisi, ardışık vertebra korpuslarının füzyonuyla sonuçlanan füzyonlu ya da füzyonsuz olarak yapılabilir. ${ }^{[17]}$ Öktenoğlu ve arkadaşları, sadece anterior diskektomi ve enstrümanla füzyon uygulanan (anterior plak vida sistemi) olguların klinik ve radyolojik sonuçlarını karşılaştırmayı amaçlayan, randomize ileriye dönük bir çalışma tasarlamışlardır. ${ }^{[21]}$ Olgu sayısı 20'dir ve görece az olarak nitelendirilebilir. Ancak, iki hafta süreklilik arzeden ya da girişimsel tedaviye yanıt vermeyen olgular çalışmaya dahil edilmişlerdir. Olgulardan $11^{\prime} \mathrm{i}$ sadece anterior diskektomi yöntemiyle, kalan dokuzu plak-vida enstrümantasyonuyla sağlanan dikektomiye eklenen füzyon yöntemiyle ameliyat edilmişlerdir. Cerrahi sonrası dönemde, her iki gruptaki üst ekstremite görsel analog değerleri (visual analog score -VAS) ortalama sekizden üçe düşmüş ve anlamlı iyileşme sağlanmıştır.

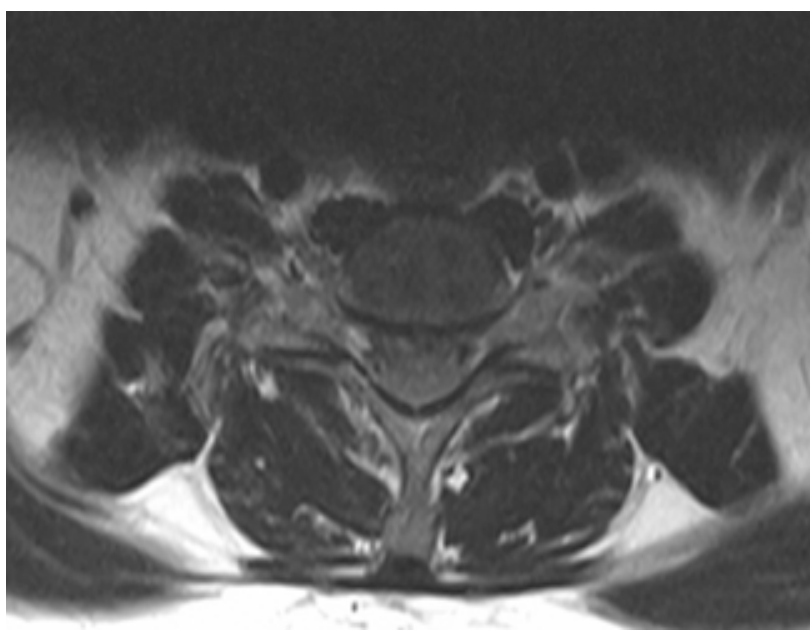

Şekil 2. Aynı olgunun MR görüntüsünde, aksiyel kesitte servikal medulla spinalise herniye olan diskin neden olduğu şiddetli orta hat basısı görülmektedir.

Birinci yılın sonunda radyolojik değerlendirme BT ile yapılmıştır. Plak uygulanan grupta foramen genişlikleri sadece diskektomi grubuna göre bir miktar daha yüksek bulunmuşsa da, anlamlı farklılık görülmemiştir. Ancak, plaklı grupta füzyon oranı \%100, plaksız grupta ise \%45 olarak saptanmıştır. Yazarlar sonuç olarak, plaksız anterior diskektomi yönteminin de tatminkâr klinik iyileşme sağladığı sonucuna varmışlardır. [21]

\section{Olgu}

Otuz dört yaşında kadın hasta, bir aydır devam eden şiddetli boyun ve her iki kola yayılan ağrı yakınmasıyla kliniğimize başvurdu. Ağrının akut başlangıçlı olduğunu ifade ediyordu. Travma öyküsü yoktu. Nörolojik bakısında belirgin nörolojik defisiti yoktu. Ancak, bilateral C 6-7 dermatomlarına uyan hiperestezi tarif ediyordu. Başvurudan önce kullandığı ağrı kesicilerden ve boyunluk uygulamasından yarar görmediğini belirtiyordu. Servikal dejeneratif patoloji zemininde radikülopati ön-tanılı olgunun pre-kontrast $M R$ görüntüsünde, $C$ 6-7 düzeyinde disk herniyasyonuyla (C 6-7 HNP) uyumlu görünüm saptandı (Şekil 1 ve 2). Dört haftalık konvansiyonel tedaviden yarar görmediğini düşünen ve şiddetli ağrı yakınması olan hasta, anterior yaklaşımla servikal diskektomi ve PEEK (polyetheretherketone) kafesle füzyon önerisini kabul etti. Erken cerrahi sonrası BT görüntülerinde (Şekil 3 ve 4), kemik pencerede füzyon amacıyla implante edilen PEEK kafes görülmektedir. 


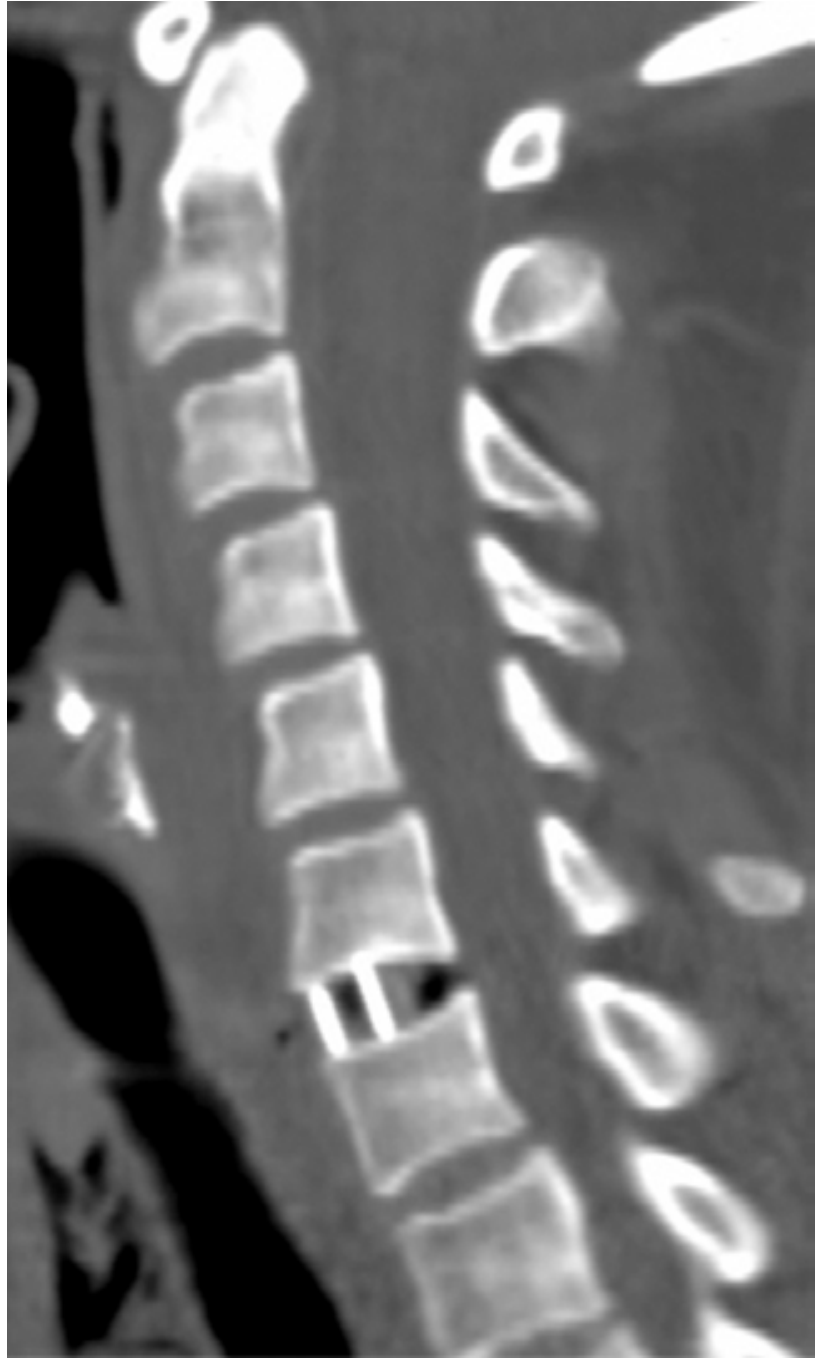

Şekil 3. Aynı olguya ait erken cerrahi sonrası dönemde elde edilen BT incelemenin sagittal rekonstrüksiyonunda, diskektomi mesafesine füzyon amacıyla yerleştirilen PEEK kafes görüntüsü. Kafesin disk mesafesinde olduğu ve disk yüksekliğinin arttığı görülmektedir.

\section{SONUÇ}

Boyun ve kol ağrısıyla prezante olan olgularda, öncelikle radyolojik ve gerekli görülürse diğer laboratuvar incelemelerle, tümör, enfeksiyon ya da travma gibi etiyolojik nedenler dışlanmalıdır. Servikal omurganın dejeneratif değişiklikleri sonucunda gelişen tek ya da çoklu seviye kök basısı ya da irritasyonuna sekonder akut ya da kronik ağrı yakınmalarında, cerrahi dekompresyon güçlü bir tedavi seçeneği olarak göz önünde tutulmalıdır. Kök dekompresyonunun amaçlandığı cerrahi yaklaşım, olgunun özellikleri ve cerrahın tecrübesi sonucunda şekillenecektir.

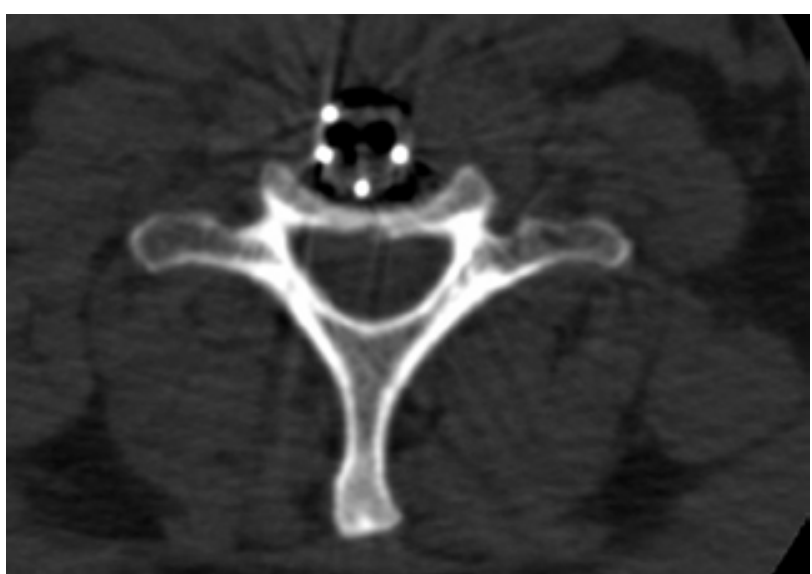

Şekil 4. Cerrahi sonrası erken dönem BT'de, kemik pencerede aksiyel kesitte diskektomi mesafesine yerleştirilen PEEK kafes görüntüsü.

\section{KAYNAKLAR}

1. Bonica JJ. The need of a taxonomy. Pain 1979;6(3):247-8.

2. Jeffries LJ, Milanese SF, Grimmer-Somers KA. Epidemiology of adolescent spinal pain: a systematic overview of the research literature. Spine (Phila Pa 1976) 2007;32(23):2630-7.

3. Côté P, Cassidy JD, Carroll L. The Saskatchewan Health and Back Pain Survey. The prevalence of neck pain and related disability in Saskatchewan adults. Spine (Phila Pa 1976) 1998;23(15):1689-98.

4. Aartun E, Hartvigsen J, Wedderkopp N, Hestbaek L. Spinal pain in adolescents: prevalence, incidence, and course: a school-based two-year prospective cohortstudy in 1,300 Danes aged 11-13. BMC Musculoskelet Disord 2014;15:187. Crossref

5. Bono CM, editor. Diagnosis and Treatment of Cervical Radiculopathy from Degenerative Disorders. North American Spine Society Evidence-Based Clinical Guidelines for Multidisciplinary Spine Care. North American Spine Society; 2010.

6. Yoss RE, Corbin KB, Maccarty CS, Love JG. Significance of symptoms and signs in localization of involved root in cervical disk protrusion. Neurology 1957;7(10):673-83.

7. Tanaka $Y$, Kokubun S, Sato T, Ozawa H. Cervical roots as origin of pain in the neck or scapular regions. Spine (Phila $\mathrm{Pa}$ 1976) 2006;31(17):E568-73.

8. Ozgur BM, Marshall LF. Atypical presentation of C-7 radiculopathy. J Neurosurg 2003;99(2 Suppl):169-71.

9. Bono CM, Ghiselli G, Gilbert TJ, Kreiner DS, Reitman C, Summers JT, Baisden JL, Easa J, Fernand R, Lamer T, Matz PG, Mazanec DJ, Resnick DK, Shaffer WO, Sharma AK, Timmons RB, Toton JF; North American Spine Society. An evidencebased clinical guideline for the diagnosis and treatment of cervical radiculopathy from degenerative disorders. Spine J 2011;11(1):64-72. Crossref

10. Van de Kelft E, van Vyve M. Diagnostic imaging algorithm for cervical soft disc herniation. J Neurol Neurosurg Psychiatry 1994;57(6):724-8.

11. Wilson DW, Pezzuti RT, Place JN. Magnetic resonance imaging in the preoperative evaluation of cervical radiculopathy. Neurosurgery 1991;28(2):175-9. 
12. Modic MT, Masaryk TJ, Mulopulos GP, Bundschuh C, Han JS, Bohlman H. Cervical radiculopathy: prospective evaluation with surface coil MR imaging, CT with metrizamide, and metrizamide myelography. Radiology 1986;161(3):753-9.

13. Ashkan K, Johnston P, Moore AJ. A comparison of magnetic resonance imaging and neurophysiological studies in the assessment of cervical radiculopathy. $\mathrm{Br} J$ Neurosurg 2002;16(2):146-8.

14. Yang HS, Oh YM, Eun JP. Cervical Intradural Disc Herniation Causing Progressive Quadriparesis After Spinal Manipulation Therapy: A Case Report and Literature Review. Medicine (Baltimore) 2016;95(6):e2797. Crossref

15. Oppenheim JS, Spitzer DE, Segal DH. Nonvascular complications following spinal manipulation. Spine J 2005;5(6):660-6.

16. Padua L, Padua R, LoMonaco M, Tonali PA. Radiculomedullary complications of cervical spinal manipulation. Spinal Cord 1996;34(8):488-92.
17. Cağlar YS, Bozkurt M, Kahilogullari G, Tuna H, Bakir A, Torun F, Ugur HC. Keyhole approach for posterior cervical discectomy: experience on 84 patients. Minim Invasive Neurosurg 2007;50(1):7-11.

18. Kotil K, Bilge T. Prospective study of anterior cervical microforaminotomy for cervical radiculopathy. J Clin Neurosci 2008;15(7):749-56. Crossref

19. Topuz K, Colak A, Kaya S, et al. Two-level contiguous cervical disc disease treated with peek cages packed with demineralized bone matrix: results of 3-year follow-up. Eur Spine J 2009;18(2):238-43. Crossref

20. Sampath P, Bendebba M, Davis JD, Ducker T. Outcome in patients with cervical radiculopathy. Prospective, multicenter study with independent clinical review. Spine (Phila Pa 1976) 1999;24(6):591-7.

21. Oktenoglu T, Cosar M, Ozer AF, Iplikcioglu C, Sasani M, Canbulat N, Bavbek C, Sarioglu AC. Anterior cervical microdiscectomy with or without fusion. J Spinal Disord Tech 2007;20(5):361-8. 